\title{
Philosophy of Science: Definition, Object of Study, Scope, and Method
}

\author{
Sulistiyowati Gandariyah Afkari \\ STAIN Kepri \\ Email: sulistiyowati@stainkepri.ac.id. \\ Ridhoul Wahidi \\ Universitas Islam Indragiri \\ Email: dhoul faqoet@yahoo.co.id \\ Ahmad Syukri \\ UIN Sulthan Thaha Saifuddin Jambi \\ Email: ahmadsyukriss@uinjambi.ac.id \\ Badarussyamsi \\ UIN Sulthan Thaha Saifuddin Jambi \\ Email: badarussyamsi@uinjambi.ac.id
}

\begin{abstract}
Philosophy of Science is the study of all human life and thought phenomena critically and described in basic concepts. Philosophy is necessary for proving an accident or phenomenon and substance because, with philosophy, it can be proven that something exists or might exist. After all, with reason, a substance can be proven, and that the substance was formed from philosophy. There are two objects of study in the philosophy of science: a) material objects and b) formal objects. The scope of the philosophy of science is threefold, namely: a) Ontology, b) Epistemology, and c) Axiology. There are ten basic methods of philosophy of science, but in this study, the author only discusses three methods: a) Positivism Method, b) Phenomenological Method, and c) Critical Method. The purpose of the philosophy of science is to break the confinement of the human mind. By understanding and studying philosophy, humans can break the ice, rigidity, and even confinement of their minds by requestioning everything that exists.
\end{abstract}

Keywords: philosophy of science, definition, object of study, scope, method

Abstrak: Filsafat Ilmu adalah studi tentang seluruh fenomena kehidupan dan pemikiran manusia secara kritis dan dijabarkan dalam konsep mendasar. Filsafat sangat dibutuhkan dalam membuktikan suatu aksiden atau fenomena dan Subtansi karena dengan filsafat bisa terbukti sesuatu itu ada atau mungkin ada, karena dengan akal bisa dibuktikan suatu substansi dan substansi itu terbentuknya dari filsafat. Objek Kajian dalam Filsafat Ilmu ada dua, yaitu: a) Objek Material dan b) Objek Formal. Ruang lingkup filsafat ilmu ada tiga, yaitu: a) Ontologi, b) Epistimologi dan c) Aksiologi. Metode filsafat ilmu pada dasarnya ada sepuluh metode, akan tetapi dalam kajian ini penulis hanya membahas tiga metode, yaitu: a) Metode Positivisme b) Metode Fenomenologi dan c) Metode Kritis. Tujuan filsafat ilmu 
sebagai pendobrak keterkungkungan pikiran manusia. Dengan memahami, dan mempelajari filsafat manusia dapat menghancurkan kebekuan, kakakuan, bahkan keterkungkungan pikirannya dengan kembali mempertanyakan segala yang ada. Kata-kata kunci: filsafat ilmu, pengertian, objek kajian, ruang lingkup, metode

\section{A. Introduction}

Philosophy is often described as a complicated discipline. Some people think of philosophy as a subversive and dangerous science. It can be seen in the history of Western philosophy, where many cases show that clergy and church theologians accused philosophy of being an instrument of the devil's accursed. Throughout the middle ages, philosophy was widely opposed by church groups-1. The style of medieval philosophy appears in the doctrine of Saint Augustine (354-430), which states Credo ut intelligam (I believe that I may understand). Augustine also emphasized that absolute truth is religious teaching taught by the church. The truth stems from the axiom that God created everything from nothing (creation ex nihilo) ${ }^{2}$. The best life, according to Augustine, is to meditate and love God ${ }^{3}$.

Philosophy has been criticized in the history of Islam because it is considered harmful to the creed of the people. Abu Hamid al-Ghazali (450-505 H/1058-1111 $\mathrm{AD}$ ) is a very sharp figure in criticizing philosophy. Two of al-Ghazali's most essential works, entitled: Maqashid al-Falasifah (The Meaning of the Philosophers) and Tahaful al-falasifah (The Intention Thoughts of Philosophers) are examples of essays that explicitly attack philosophy ${ }^{4}$.

Despite sharp criticism, philosophy continues to thrive. Even philosophy has been positioned as Scientiarum or the mother of all sciences ${ }^{5}$. For although philosophy does not teach to make bread", philosophy is beneficial because it can prepare the stove, remove stains from the flour, increase the amount of seasoning and lift the bread from the stove at the right time ${ }^{6}$. This illustration confirms that philosophy leads us to the proper understanding. Furthermore, that understanding leads us to more appropriate actions and positions humans as Homo Sapiens: Humans the Thinker ${ }^{7}$, who knows whatever is known, whether rational-empiricalmethod or not ${ }^{8}$.

It means that philosophy has a vital role in human life, as a comprehensive, radical, and rational view of everything that exists 9 . In this context, the philosophy of science is no exception having an essential role in human life because it is a mater Scientiarum or mother of science ${ }^{10}$, whose knowledge of being is essential to put forward, as stated in this paper.

${ }^{1}$ Jan Hendrik Rapar, Pengantar Filsafat, (Yogyakarta: Kanisius, 1995), p. 12

2Antony Flew, A Dictionary of Philosophy, (New York: St. Martin's Press, 1984), p. 31

${ }^{3}$ Ahmad Tafsir, Filsafat Umum, (Bandung: Remaja Rosdakarya, 1992), p. 100

${ }^{4}$ Mulyadi Kertanegara, "Ilmu Kalam", dalam Taufiq Abdullan, et al. (Ed), Ensiklopedi Tematis Dunia Islam, Ch. 4, (Bandung: PT. Ikhtiar Baru Van Hoeve, 2002), pp. 124-125.

5Jan Hendrik Rapar, Pengantar Filsafat, (Yogyakarta: Kanisius, 1995), p. 11.

${ }^{6}$ Louis Kattsoff, Pengantar Filsafat, translation. Soejono Soemargono, (Yogyakarta: Tiara Wacana, 1996), p. 3.

${ }^{7}$ Gilbert Highet, as stated by Jujun S. Suria Sumantri, Ilmu Dalam Perspektif, (Jakarta: Gramedia, 1985), p. 41.

${ }^{8}$ Ahmad Tafsir, Filsafat Ilmu Mengurai Ontologi, Epistemologi, dan Aksiologi Pengetahuan, (Bandung: Remaja Rosdakarya, 2004), p. 34.

${ }^{9}$ Suwardi Endraswara, Filsafat Ilmu: Konsep, Sejarah, dan Pengembangan Metode Ilmiah (Revision edition). (Yogyakarta: Center for Academic Publishing Service 2015), p. 43.

${ }^{10}$ Rusliana, Filsafat Ilmu, (Bandung: PT. Refika Aditama 2017), p. 67. 


\section{Understanding the Philosophy of Science}

The term philosophy comes from the Greek Philosophia, which consists of two words: Philos, which means love, and Sophia, which means wisdom. According to Plato, philosophy is discovering absolute reality or truth through dialectics Meanwhile, al-Farabi explained philosophy as the science of the natural world, which aims to find out the true nature. Meanwhile, Ibn Rusd stated that philosophy is an autonomous knowledge that needs to be studied by humans because it is given the gift of reason ${ }^{11}$. Meanwhile, according to Susanto, philosophy is a science that seeks to examine problems that arise and relate to everything, both material and immaterial, in earnest to discover the true nature of things ${ }^{12}$.

If we pay close attention, it appears that the meanings mentioned above are complementary, so philosophizing means an investigation of what, how, and for what, which when associated with philosophical terminology, is included in issues of ontology, epistemology, and axiology ${ }^{13}$.

Meanwhile, science in the study of the philosophy of science contains three meanings, namely science as a product, science as a method, and science as a process. As a product of science, it is a collection of knowledge, as a method of science is a series of working processes to obtain proven knowledge. In contrast, as a process, science is concerned with implementing research activities that produce knowledge ${ }^{14}$. In this understanding, science is the arrangement or collection of knowledge obtained through research and experimentation from facts (science is organized knowledge obtained by observation and testing facts) ${ }^{15}$. Here two critical things are seen, namely the words science and observation. These two words are significant because they have an inseparable correlation ${ }^{16}$.

The understanding of philosophy and science above can be interpreted as investigating the characteristics of scientific knowledge and ways to obtain it. In other words, the philosophy of science is a follow-up investigation because if the organizers investigate objects and problems of a particular type from each science itself, then people can carry out further investigations of these scientific activities. By diverting attention from the actual objects of scientific inquiry to the process of inquiry itself ${ }^{17}$. It is in this context that The Liang Gie defines the philosophy of science as all reflective thoughts on issues concerning all matters concerning the foundation of science and the relationship of science to all aspects of human life ${ }^{18}$.

A brief overview of the meaning of the philosophy of science can be summarized into three, (1) A critical study of the methods used by particular sciences; (2) Efforts to seek clarity on the basic concepts of science and efforts to unmask the basics of empiricism, rationality, and pragmatism, and; (3) A joint study

${ }^{11}$ Amsal Baktiar. Filsafat Ilmu Cet XI, (Jakarta; Rajawali Pers, 2012), p. 4.

${ }^{12}$ Ahmad Susanto. Perkembangan Anak Usia Dini, (Jakarta: Kencana Prenada Media Group, 2011), p. 48.

${ }_{13}$ See Jujun S. Suriasumantri, Filsafat Ilmu Sebuah Pengantar Populer, (Jakarta: Pustaka Sinar Harapan, 2000), p. 22.

${ }^{14}$ Abd Mui Salim. et al. Metodologi Penelitian Tafsir Maudhu'iy, (Makassar: Alauddin Pers, 2009), p. 45.

${ }^{15}$ Cecep Sumarna, Filsafat Ilmu Dari Hakikat Menuju Nilai, (Bandung: Pustaka Bani Quraisy, 2004), p. 23.

16Suriasumantri, op cit., p. 6.

${ }^{17}$ Soejono Soemargono, Pengantar Filsafat Ilmu, (Yogyakarta: Tiara Wacana Yogya, 2003), p. 1

${ }^{18}$ Rizal Mustansyir dan Misnal Munir, Filsafat Ilmu, (Yogyakarta: Pustaka Pelajar Offset, 2010), 49. 
consisting of several diverse studies set clear boundaries regarding a particular science.

Every science has a particular object as the field of investigation or study. This object is obtained through a specific approach or perspective, method, and system. The existence of an object makes every science different from one another. The object of the philosophy of science, according to Surajiyo, is something that is the material of research or knowledge formation ${ }^{19}$.

The material object of philosophy of science overlaps with all sciences, namely, discussing the facts and truths of all disciplines and confirmation and logic used by all disciplines. Meanwhile, according to Arif Rohman, Rukiyati, and L. Andriani, the material object is a material in the form of objects, goods, circumstances, or things being studied ${ }^{20}$. According to Surajiyo, a material object is the subject of research or the formation of that knowledge. Material objects are also investigated, viewed, or highlighted by a scientific discipline. Material objects include anything, both concrete and abstract things ${ }^{21}$. According to Waryani Fajar Riyanto, the material object is the material target of an investigation, thought, or scientific research. It can be anything, whether material objects or non-material objects. It is not limited to whether only in concrete realities such as humans or the universe or only in abstract realities such as God or something divine ${ }^{22}$.

The formal object of the philosophy of science is the philosophical study of facts and truth and the philosophical study of confirmation and logic. Facts and truths become substantive formal objects, while confirmation and logic become formal instrument objects in the study of the philosophy of science. A formal object is a figure of a material object that is seen and approached with a particular point of view and perspective or, in other terms, the ability of human thinking to obtain correct knowledge. ${ }^{23}$. Meanwhile, the formal object, according to Waryani Fajar Riyanto, is a particular point of view that is owned and determines one kind of knowledge 24 . According to Surajiyo, the formal object of the philosophy of science is the point of view aimed at the material of the research or formation of knowledge, or the angle from which the material object is highlighted ${ }^{25}$. In Liang Gie's view, the formal object is the center of attention in the scientist's study of the phenomenon. The combination of material objects and formal objects so that it is a particular subject discussed in scientific knowledge is the actual object of the branch of science concerned ${ }^{26}$.

The scope of the field of study of the philosophy of science is developing continuously, and this cannot be separated from the increasingly intense interaction between philosophy and science. The field of study that has become the study of the philosophy of science has also developed, and between experts, there are differences in determining the scope of the study of the philosophy of science, although the main field of study tends to be the same. The difference is more visible in the details of the topic of study. According to Edward Madden, the scope/fields of

${ }^{19}$ Surajiyo, Ilmu Filsafat: Suatu Pengantar, (Jakarta: Bumi Aksara, 2007), p. 5.

${ }^{20}$ Arif Rohman, Rukiyati, dan L. Andriani, Mengenal Epistimologi dan Logika Pendidikan, (Yogyakarta: Pustaka Pelajar, 2011), p. 22.

${ }^{21}$ Surajiyo, loc. cit.

${ }^{22}$ Waryani Fajar Riyanto, Filsafat Ilmu Topik-topik Estimologi, (Yogyakarta: Integrasi Interrkoneksi Press,2011), p. 20.

${ }^{23}$ Rohman, et al, Mengenal Epistimologi, p. 22.

${ }^{24}$ Riyanto, Filsafat Ilmu, p. 20.

${ }^{25}$ Surajiyo. op. cit., p. 7.

${ }^{26}$ Mustansyir and Munir, Filsafat Ilmu, p. 139. 
study in the philosophy of science are Probability, Induction, and Hypotheses. Meanwhile, according to Ernest Nagel, the philosophy of science has the following scope: Logical pattern exhibited by explanation in the sciences, Construction of scientific concepts, and Validation of scientific conclusions ${ }^{27}$.

From this opinion, it appears they are more like adding to the scope of the study of the philosophy of science. Jujun S. Suriasumantri stated that the philosophy of science is part of epistemology which examines the nature of science explicitly. In education, the philosophy of science occupies a position analogous to other sciences by asking questions in the form of questions. The philosophy of science is a study related to what objects are studied by science (ontology), how the process of acquiring knowledge (epistemology), and how the benefits of science (axiology).

Ontology questions about what exists or about reality) in this universe, which includes: nature (cosmos), humans (Anthropos), and God (Theos), so that it is known that there is a natural philosophy (cosmology), human philosophy (philosophical anthropology), and divine philosophy (theology). It also includes non-physical reality or outside the physical world (beyond the physical), such as supernatural things ${ }^{28}$.

If viewed in Greek, it consists of two words: being, logos, Logic. So ontology is The theory of being qua being or the theory of existence as existence ${ }^{29}$. Meanwhile, the term ontology is the science that discusses the nature that exists in physical/concrete or spiritual/abstract. ${ }^{30}$. Likewise, according to another source, it is stated that the ontology discusses what we want to know, how far we want to know, or in other words, a study of the theory of "being"31.

An example of an ontology commonly applied in everyday life is a table. In the table ontology, it uses the reality of the table. The reality is that an image or idea makes us recognize a table. No matter how many models of tables there are, the object is still a table, no matter what size, color, and physical difference. It is the reality of the ideas and images that exist.

The following are some definitions of ontology: Sidharta Darji Darmodiharjo: The branch of philosophy that discusses the rational principles of existing reality 32 . Levinas: Ontology is the total, comprehensive knowledge of 'being'33. Aristotle: Ontology is a science that investigates the nature of something or about existence, existence or existence and equates its meaning with metaphysics ${ }^{34}$. Pandji Setijo: is a field of philosophy that investigates the nature of all existing realities to determine the truth or reality as can be achieved with knowledge ${ }^{35}$. Muljamil Qomar: In his

${ }^{27}$ Suriasumantri, loc. cit.

28Darwis A. Soelaiman, Filsafat Ilmu Pengetahuan perspektif Barat dan Islam, (Bandar Publising: 2019), p. 12.

${ }^{29}$ Amsal Bahtiar, Filsafat Ilmu, (Jakarta: PT Raja Grafindo Persada, 2012), p. 132.

30Ibid., p. 134.

31Jujun S. Suriasumantri, Ilmu dalam Perspektif, (Jakarta: Gramedia, 1985), p. 5.

${ }^{32}$ Darmodiharjo, Darji, Shidarta, Pokok-pokok filsafat hukum: apa dan bagaimana filsafat hukum Indonesia, (Jakarta: Gramedia). p. 9.

33Wibowo, Ignatus and B Herry Priyono, Sesudah filsafat: esai-esai untuk Franz Magnis-Suseno. (Yogyakarta: Kanisius. 2006), p. 54.

${ }^{34}$ Muhdi, Ali, et al., Merevitalisasi Pendidikan Pancasila Sebagai Pemandu Rreformasi, (Surabaya: IAIN Sunan Ampel Press, 2012), p. 249.

${ }^{35}$ Setijo, Pandji, Pendidikan Pancasila Perspektif Sejarah Perjuangan Bangsa, (Jakarta: Grasindo, 2009), p. 57. 
book, he explains that ontology is a theory of "being", which is about the reality of what is thought, which becomes the object of thought ${ }^{36}$.

Let us look at some of the meanings of the ontology above. It can be concluded that ontology is a study in philosophy that focuses on discussing all existing realities (Being) in total without being bound by one particular embodiment that is universal and essential. Alternatively, it can be said that ontology is "The theory of being qua being (theory of being as existence)."

Epistemology or theory of knowledge, which questions the truth (truth), includes the basis or source of knowledge, breadth of knowledge, methods of knowledge, and truth of knowledge. There is also inserting logic into the scope of epistemology because logic is a part of philosophy that discusses the means of logical thinking 37 .

It is a philosophical study that underlies the foundations of knowledge, and the theory of human knowledge begins. In other words, epistemology is a fundamental and systematic thought about knowledge. It is a branch of philosophy that discusses the occurrence of knowledge, sources of knowledge, origins of knowledge, methods or ways of obtaining knowledge, validity, and truth of knowledge.

According to Pandji Setijo, epistemology is a field of philosophy that discusses the sources, limits, processes, and validation of knowledge itself which includes the means and ways of using the means and sources of knowledge to achieve success or rational, critical, reality phenomenological, and positivist ${ }^{38}$. Muljamir Qomar, states epistemology as a theory of knowledge that discusses how to get knowledge from the object to be thought of. Dagobert D. Runes: Epistemology is a branch of philosophy that deals with the source, structure, method, and validity of knowledge. Azyumardi Azra: Epistemology is a science that discusses the authenticity, understanding, structure, methods, and validity of science. Paul Suparno: Epistemology deals with the origins that shape scientific knowledge ${ }^{39}$. Kattsoff: epistemology is the branch of philosophy that deals with the origin, structure, methods, and validity of knowledge ${ }^{40}$.

From the description above, epistemology is one of the branch studies of philosophy that underlies how science begins. So it is a fundamental systematic thought about knowledge and discusses the origin of knowledge, methods, or ways of obtaining knowledge, validity, and truth of knowledge.

The language of axiology comes from the words Axios (Greek), which means value, and the word Logos which means; theory, so axiology implies; theory of value $^{41}$. While in general, axiology can be interpreted as a theory of value related to the usefulness of the knowledge gained ${ }^{42}$. Axiology is also referred to as the theory of value, desirable, wanted, or good. Axiology discusses the purpose of science; what knowledge is used for; How is the relationship between how to use the knowledge according to moral rules; How to determine the object under study based on moral

\footnotetext{
${ }^{36}$ Qomar, Mujamil, Epistemologi Pendidikan Islam-Dari Metode Rasional hingga Metode Kritik, (Jakarta: Erlangga, 2006), p. 1

${ }^{37}$ Soelaiman, Darwis A, Filsafat Ilmu Pengetahuan perspektif Barat dan Islam, (Bandar Publishing: 2019), p. 12.

38Setijo, Pendidikan Pancasila, p. 57.

${ }^{39}$ Qomar, Epistemology, pp. 4-6

${ }^{40}$ Darmodiharjo, Pokok-pokok filsafat hukum, p. 9

${ }^{41}$ Burhanuddin Salam, Logika Materil: Filsafat Ilmu Pengetahuan, (Jakarta; Reneka Cipta, 1997), p. 68.

${ }^{42}$ Jujun S. Suriasumantri, Filsafat Ilmu Sebuah Pengetahuan Populer, (Jakarta: Pustaka Sinar Harapan, 2017), p. 234.
} 
choices; Auxologists try to formulate a consistent theory for ethical behavior. In the heart, he asks like "what is good?"

Lorens Bagus: A philosophical study of the nature of value can be answered in 3 different ways, a) value is entirely subjective, b) value is a reality, but does not exist in space and time, c) values are objective elements that compose reality ${ }^{43}$. Pandji Setijo: axiology is a field that investigates values, primarily normative values $^{44}$. Bustanuddin Agus: in his book, states that "axiology discusses what and how certain knowledge functions for human life".45. Mujamil Qomar (2006:1): axiology is a theory of value that discusses the benefits, uses, and functions of the object being considered ${ }^{46}$

Axiology is a branch of philosophy that describes the uses and benefits of the results obtained through thoughts. Axiology refers to how and what values or ethics (morality). The beauty of the knowledge gained can be applied in human life following the rules.

Philosophy means free from existing theories, hypotheses, and definitions. So in their attempt to describe a general method of philosophy, many methodologists have run back to the general methodical elements, for example, by saying that philosophy applies the inductive-deductive method. However, this does little to explain what the philosophical method is. Therefore, perhaps the best way is to take a concrete look at the methods used by each or every philosopher and their philosophical explorations. Throughout the history of philosophy, several different philosophical methods have been developed.

Facing Auguste Comte's positivist philosophy, on the one hand, people say that philosophy is nothing more than a method or stance. While on the other hand, people say that the philosophy of positivism is an "affirmation system," a concept about the world and humans. HJ Pos argues that the history of science in the 19th century cannot be written without positivism.

One cannot deny that Auguste Comte's philosophy of positivism has its meaning and place only in the field of Western philosophy. At the same time, its influence is widespread, not only in philosophy but also in other fields or branches of science. The term "positivism" for a school of philosophy reappeared in the 20th century today, namely with the presence of the 19th-century positivism philosophy and 20th-century positivism philosophy ${ }^{47}$.

Auguste Comte had shown that there is progress in the development of the human soul, both individually and as a whole. Furthermore, progress is achieved when development comes at the so-called positive moment. Auguste Comte argues that the "law" of development can be explained by humankind's tendency to strive so that he can continuously improve his nature and condition. In the meantime, the progress is in social life and the advancement of science or "scientific knowledge."Auguste Comte then divides speculative or theoretical science into abstract or general science and concrete or specific science. To prove the progress human have made in their knowledge, Auguste Comte took a method by conducting a classification (classification) of science.

\footnotetext{
43Bagus, Lorens, Kamus Filsafat, (Jakarta: Gramedia, 2005), pp. 33-34

${ }^{44}$ Setijo, Pendidikan Pancasila, p. 57.

${ }^{45}$ Agus, Bustanuddin, Pengembangan ilmu-ilmu sosial: studi banding antara pandangan ilmiah dan ajaran Islam, (Jakarta: Gema Insani Press. 1999), p. 20.

${ }^{46}$ Qomar. Epistemologi Pendidikan, p.30

${ }^{47}$ Koento Wibisono, Arti Perkembangan Menurut Filsafat Positivisme Aguste Comte, (Yogyakarta: Gadjah Mada University Press, 1982), p. 36.
} 
Auguste Comte acknowledged that the goal of science ultimately leads to the attainment of power. As the motto says "knowledge is power" but we must not forget another higher goal. Science gives satisfaction to humans by introducing laws of phenomena of the universe. By knowing the laws of phenomena, humans will be able to predict and even change nature for their benefit.

Besides positivism, Phenomenology is a philosophical school developed by a German philosopher, Edmund Husserl. The word phenomenology consists of two formed words, namely phenomenon and logos. The word phenomenon has almost the same meaning as fantasy, phantom, phosphor, photo, which means light or light. When formed into a verb, the word root means: to appear, be seen by the light, and shine. The phenomenon, thus, can be interpreted as something visible because it shines. In Indonesian, some words mean phenomena, namely: symptoms ${ }^{48}$.

Phenomenology means a description or discussion of a phenomenon, something manifesting itself, or something symptomatic. Phenomenology essentially wants to achieve the proper understanding, namely an understanding that captures reality as desired by the reality itself 49 .

According to Phenomenology, the reality is a place where humans meet and unite with reality. In that meeting, reality manifests itself and causes symptoms but hides. Human understanding of something can increase, become perfect. The increase and perfection of understanding are because humans always investigate, ask questions, and keep asking. Asking is a human activity to remove the blur that surrounds reality. Reality manifests itself, but along with it, it is also veiled (onthulling \pm verhulling). Humans try to remove or remove the veil to be able to see reality 50 .

The fog that shrouds reality is from the side of reality and those who see reality. Human conceptions, ways of thinking, living conditions, and backgrounds often become a thick fog in seeing reality. The conceptions, ways of thinking, living conditions, and backgrounds that become foggy for people to see reality are not only from themselves. However, they are sometimes planted, put into the heart by the times they experience. Husserl suggested that for humans to arrive at reality, they must break away from the various darknesses and break through the fog. Husserl's term, "Nach Den Sachen Selbst," means we have to break through the fog to get to reality 51 .

As a philosophical method used by Husserl, Phenomenology aims to explain that human knowledge has "Rechtsanspruch auf Gegestanliehkeit" which means we understand. In that sense, we can say that understanding has an object (Gegenstand). But is it true? What is being questioned is the truth of human understanding in general, and then Husserl questioned the truth of science in particular.

It is necessary to look at the everyday human experience in experiencing understanding to solve the problem. People often encounter dark things, which makes it difficult or hinders the truth's achievement. Humans have an ordinary or spontaneous stance. The Husserl term "Naturliche Einstellung" humans are aware of the world because it can be seen, heard, touched, and so on. All of that is spontaneously recognized by humans as objective. That is the usual sense ${ }^{52}$.

\footnotetext{
483N. Drijarkara, Percikan Filsafat, (Jakarta: PT Pembangunan, 1989), p. 116.

${ }^{49}$ Drijarkara, Ibidl., p. 118.

50Mary Warnock, Existensialism, (New York \& Oxford: Oxford University Press, 1989), p. 26.

${ }^{51}$ Drijarkara, op. cit., p. 117.

${ }^{52}$ Warnock, op. cit., p. 26.
} 
The philosopher's ordinary understanding is not enough. To get a perfect understanding, he must think. He must contemplate because there are also subjective elements in that spontaneous stance. Those who want to meet the actual reality, according to Husserl, must have the courage to leave the usual position. This preoccupation by Husserl called "Phenomenon Logische Reduction "Reduction means filtering, which filters "Erlebnisse" of our experiences. If it has been filtered, what remains is a phenomenon in its pure form ${ }^{53}$.

In addition to the above, Husserl also offers other ways. Phenomena usually always point to things outside of our awareness. We usually just get attracted to reality, and because we "get lost" then we just admit this and that. In such conditions, the meaning is not pure. We have many assumptions and feelings that all slip into our understanding. To achieve pure understanding, we must dare to look only at phenomena qua phenomena.

So that humans can see phenomena as they are, they should not be hasty in making judgments and conclusions. Humans, in general, tend to make affirmations or admit, for example, this does exist, that is how it is, and so on. It is these judgments and conclusions that must be withheld. Hold on to all decisions, put off every thought that arises about the reality we perceive.

The words withhold or delay interpret Husserl's term "Einklammern, " which means to confine. For example, when we read a complex text, we put many brackets to understand the essence. Things that are considered lacking need to be locked first because what will be searched for is the essence of the text first. This activity by Husserl is called phenomenological screening 54 .

Has the path offered by Husserl finished knowing the reality? Not, there is still a second purge, which Husserl calls ideation. This activity is also called reduction, but now it is no longer phänomenologisch but "eidetish" which means filtering down to the eidos, to the essence, or the Wesen. Therefore the results of this filtering are called "wesenchau", meaning we see the essence of something 55.

Finally, there is the method of criticism. Socrates and Plato initially used this method. The philosophers before Socrates were more interested in researching and thinking about the cosmos. Socrates directed him to humans, especially about the ethical aspects. This method is based on the fact that much of human knowledge and opinion is fictitious. Knowledge of all this is even more on the essential issues of life, such as happiness and virtue. As it turns out, there is a lot of ambiguity and conflict in their knowledge, and most of them pretend to know. Socrates realized that he did not know these basic things (apologia). However, at least he knows that he does not know and wants to know. To know which knowledge is the most powerful among the many pieces of knowledge, he must be critical. How to? The answer is like the work of a midwife. Why midwife? It is not surprising, for Socrates' mother was a midwife. On several occasions, Socrates says that he is a midwife, but a midwife of knowledge and thought. He believes that everyone has the potential for proper understanding hidden in his soul. The human soul can know the essence of things, but because it is buried by pseudo-knowledge, that understanding must be opened, dismantled, cleaned, and reborn. All this can be helped by a 'midwife'. Socrates proposes a description or asks for a concrete example for every formulation put forward. Then a comparison or question is raised. This process is

\footnotetext{
53Ibid., p. 29.

${ }^{54}$ Ibid.,

${ }^{55}$ Ibid., p. 33.
} 
called 'elenchus' (denial). Answers often show contradictions in the formulation and gaps between the formulation and the example or between statements. Each statement is parsed and each term defined. It is an induction process, "virtue and righteousness," and various other terms. If necessary, use an analogy. From this, generalizations are sought, and a general understanding is formulated, namely a definition that includes all and excludes what should not be included.

This method analyzes terms and opinions, then systematized in hermeneutics which explains beliefs and shows contradictions. By asking (dialogue), distinguishing, cleaning, eliminating, and rejecting, in the end, the best of them will be found. It should be said to be the essence of something, of course, until a new 'nature' emerges through the critical method again.

Socrates' method usually does not achieve definitive results. After peeling and disassembling, it is often impossible to formulate a general nature or formulation. What is certain is that this method results in many people being critical. Many things that have been accepted as modest and peaceful by Socrates are challenged and doubted. All pillars of certainty will be shaken, and all truth will be shaken. All of this creates shocks and crises. Finally, Socrates is considered to disrupt stability and undermine the ruler's authority. He was accused of subversion and tried, then sentenced to death. However, the method was not punishable by death but continued to evolve.

The development of this method was carried out by his student Plato. There is an essential difference between this teacher and student. In contrast to Socrates, Plato argues that he, or man, already has some definitive knowledge and definite formulation. It is then fostered and developed definitive knowledge and other definite formulations from here. If Socrates was more in charge of breaking down and dismantling, Plato began to build on the ruins of the demolition. One way to build it is to decide on a definition, propose a hypothesis, carry out an analysis and finally formulate a conclusion ${ }^{56}$.

Philosophy is an attempt to think clearly about reality, and this effort produces several roles for humans ${ }^{57}$. Philosophy acts like a battering ram, meaning that philosophy breaks the confines of the human mind. By understanding and studying philosophy, humans can break the rigidity, normative, and even confinement of their minds by re-questioning everything. This breakthrough can make humans free from freeze and confinement. So, for humans, philosophy plays a role as a liberator of the human mind. This liberation guides people to think further, more profoundly, and critically of everything so that humans can clarify and explain all reality. The third role that philosophy has for humans is as a guide. In addition to having a role for humans, philosophy also plays a role in science in general. According to Descartes, philosophy is a collection of all knowledge whose investigation base is God, nature, and humans.

In carrying out its role, philosophy has a purpose. According to Plato, philosophy is a science that seeks to reach the original and pure truth. The goal of philosophy is to reach the truth. Unlike religion which relies on itself and teaches obedience, philosophy relies on critical thinking skills. Concretely, the benefits of studying philosophy are: (1) Philosophy helps educate, build oneself with a deeper mind; (2) Philosophy provides habits and intelligence to see and solve problems in everyday life; (3) Philosophy provides a broad view, stems from acism and accucentrism (in all things only see and prioritize the interests and pleasures of the

56Wibisono, Koento, Arti Perkembangan Menurut Filsafat Positivisme Aguste Comte, (Yogyakarta: Gadjah Mada University Press, 1982), p. 22.

${ }^{57}$ Eka Martini, Filsafat Umum, (Palembang: Noer Fikri Offset, 2012), p. 10. 
me); (4) Philosophy is an exercise to think for yourself so that we do not just go along with it, help the public view, believe in every slogan in the newspapers, but critically investigate what people say, have their own opinion, stand-alone, to seek the truth; (5) Philosophy provides the foundations, both for our own lives (especially in ethics) and other sciences, such as sociology, psychology, education, and so on ${ }^{58}$.

\section{Closing}

From the explanation above, it can be concluded that the Philosophy of Science is the study of all phenomena of human life and is thought critically and is described in basic concepts. Philosophy is very much needed in proving an accident or phenomenon and substance because, with philosophy, it can be proven that something exists or may exist. After all, the substance can be proven with sense, and that substance is formed from philosophy. Philosophy of science is a means of testing scientific reasoning to become critical of scientific activities. Philosophy of science is an attempt to reflect, test, and criticize assumptions and scientific methods. Because the tendency to apply a scientific method ignores the structure of science itself, one attitude that is needed here is to apply the scientific method by the structure of science, not the other way around.

\section{BIBLIOGRAPHY}

A. Fuad Ihsan, Filsafat Ilmu, Jakarta:PT. Renika Cipta, 2010.

Abd Mui Salim, et al. Metodologi Penelitian Tafsir Maudhu'iy. Makassar: Alauddin Pers, 2009.

Agus, Bustanuddin, Pengembangan ilmu-ilmu sosial: studi banding antara pandangan ilmiah dan ajaran Islam. Jakarta: Gema Insani Press, 1999.

Ahmad Susanto. Perkembangan Anak Usia Dini. Jakarta: Kencana Prenada Media Group, 2011.

Ahmad Tafsir, Filsafat Ilmu Mengurai Ontologi, Epistemologi, dan Aksiologi Pengetahuan. Bandung: Remaja Rosdakarya, 2004.

Ahmad Tafsir, Filsafat Umum. Bandung: Remaja Rosdakarya, 1992.

Amsal Bahtiar, Filsafat Ilmu. Jakarta: PT Raja Grafindo Persada, 2012.

Antony Flew, A Dictionary of Philosophy. New York: St. Martin's Press, 1984.

Bagus, Lorens. Kamus Filsafat. Jakarta: Gramedia. 2005.

Burhanuddin Salam, Logika Materil; Filsafat Ilmu Pengetahuan. Jakarta; Reneka Cipta, 1997.

Cecep Sumarna, Filsafat Ilmu Dari Hakikat Menuju Nilai. Bandung: Pustaka Bani

Quraisy, 2004.

Darmodiharjo, Darji, Shidarta, Pokok-pokok filsafat hukum: apa dan bagaimana filsafat hukum Indonesia. Jakarta: Gramedia.

Drijarkara, N., Percikan Filsafat, Jakarta: PT Pembangunan, 1989.

Highet, Gilbert, Ilmu Dalam Perspektif, Jakarta: Gramedia,1985.

Kattsoff, Louis, Pengantar Filsafat, Yogyakarta: Tiara Wacana, 1996.

Kertanegara, Mulyadi, "Ilmu Kalam", dalam Taufiq Abdullan, dkk (ed), Ensiklopedi

Tematis Dunia Islam, Jilid 4. Bandung: PT. Ikhtiar Baru Van Hoeve, 2002.

${ }^{58}$ A. Fuad Ihsan, Filsafat Ilmu, (Jakarta:PT. Renika Cipta, 2010), p. 32. 
Latif, Mukhtar. Orientasi ke Arah Pemahaman Filsafat Ilmu. Jakarta: Kencana, 2015. Martini, Eka, Filsafat Umum. Palembang: Noer Fikri Offset, 2012.

Muhdi, Ali, et al, Merevitalisasi Pendidikan Pancasila Sebagai Pemandu Rreformasi. Surabaya: IAIN Sunan Ampel Press. 2012.

Qomar, Mujamil. Epistemologi Pendidikan Islam-Dari Metode Rasional hingga Metode Kritik. Jakarta: Erlangga, 2006.

Rapar, Jan Hendrik, Pengantar Filsafat. Yogyakarta: Kanisius, 1995.

Rusliana, Iu.. Filsafat Ilmu. Bandung: PT. Refika Aditama 2017.

Setijo, Pandji. Pendidikan Pancasila: Perspektif Sejarah Perjuangan Bangsa. Jakarta: Grasindo, 2009.

Siagian, Sondang P. Filsafat Administrasi (Edisi Revisi). Jakarta: PT. Bumi Aksara, 2016.

Soejono Soemargono, Pengantar Filsafat Ilmu. Yogyakarta: Tiara Wacana Yogya, 2003.

Soelaiman, Darwis A, Filsafat Ilmu Pengetahuan perspektif Barat dan Islam. Bandar Publising: 2019.

Suriasumantri, Ilmu dalam Perspektif. Jakarta: Gramedia, 1985.

Suriasumantri, Jujun S., Filsafat Ilmu Sebuah Pengantar Populer. Jakarta: Pustaka Sinar Harapan, 2000

Suwardi Endraswara, Filsafat Ilmu: Konsep, Sejarah, dan Pengembangan Metode Ilmiah (Revision Edition). Yogyakarta: Center for Academic Publishing Service, 2015.

Warnock, Mary, Existensialism. New York \& Oxford: Oxford University Press, 1989.

Wibisono, Koento, Arti Perkembangan Menurut Filsafat Positivisme Aguste Comte, Yogyakarta: Gadjah Mada University Press, 1982.

Wibowo, Ignatus dan B Herry Priyono. Sesudah filsafat: esai-esai untuk Franz Magnis-Suseno. Yogyakarta: Kanisius, 2006. 